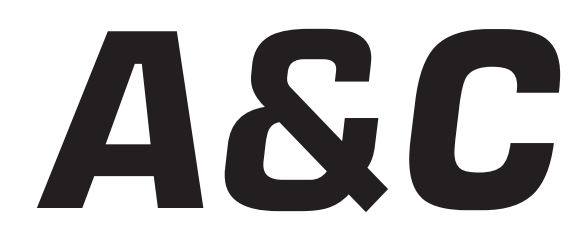

Revista de Direito Administrativo \& Constitucional

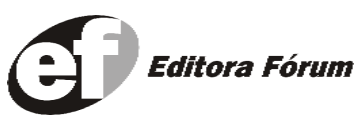

A\&C R. de Dir. Administrativo e Constitucional, Belo Horizonte, ano 5, n. 22, p. 1-253, out./dez. 2005 


\section{A\&C REVISTA DE DIREITO ADMINISTRATIVO E CONSTITUCIONAL}

\section{IPDA}

Instituto Paranaense

de Direito Administrativo

Direção Geral

Romeu Felipe Bacellar Filho

Direção Editorial

Paulo Roberto Ferreira Motta

Direção Executiva

Emerson Gabardo

Conselho de Redação

Edgar Chiuratto Guimarães

Adriana da Costa Ricardo Schier

Célio Heitor Guimarães

Conselho Editorial

Adilson Abreu Dallari

Alice Gonzáles Borges

Carlos Ari Sundfeld

Carlos Ayres Britto

Carlos Delpiazzo

Cármen Lúcia Antunes Rocha

Celso Antônio Bandeira de Mello

Clèmerson Merlin Clève

Clóvis Beznos

Enrique Silva Cimma

Eros Roberto Grau

Fabrício Motta

Guilhermo Andrés Muñoz (in memoriam)

Jaime Rodríguez-Arana Muñoz

Jorge Luís Salomoni
José Carlos Abraão
José Eduardo Martins Cardoso

José Luís Said

José Mario Serrate Paz

Juan Pablo Cajarville Peruffo

Juarez Freitas

Julio Rodolfo Comadira

Luís Enrique Chase Plate

Lúcia Valle Figueiredo

Manoel de Oliveira Franco Sobrinho

(in memoriam)

Marçal Justen Filho

Marcelo Figueiredo

Márcio Cammarosano

Maria Cristina Cesar de Oliveira
Nelson Figueiredo

Odilon Borges Junior

Pascual Caiella

Paulo Eduardo Garrido Modesto

Paulo Henrique Blasi

Paulo Neves de Carvalho (in memoriam)

Paulo Ricardo Schier

Pedro Paulo de Almeida Dutra

Regina Maria Macedo Nery Ferrari

Rogério Gesta Leal

Rolando Pantoja Bauzá

Sérgio Ferraz

Valmir Pontes Filho

Yara Stropa

Weida Zancaner

\footnotetext{
A246 A\&C Revista de Direito Administrativo e Constitucional. ano 3, n. 11, jan./mar. 2003. Belo Horizonte: Fórum, 2003.

Trimestral

ano 1, n.1, 1999 até ano 2, n.10, 2002 publicada pela Editora Juruá em Curitiba

ISSN: 1516-3210

1. Direito Administrativo. 2. Direito Constitucional. I. Fórum.
}

CDD: 342 CDU: 33.342

(c) Editora Fórum Ltda. 2005

Todos os direitos reservados. É proibida a reprodução total ou parcial, de qualquer forma ou por qualquer meio eletrônico ou mecânico, inclusive através de processos xerográficos, de fotocópias ou de gravação, sem permissão por escrito do possuidor dos direitos de cópias (Lei $n^{\circ}$ 9.610, de 19.02.1998).

Editora Fórum Ltda

Av. Afonso Pena, 2770 - 15\%16ªndar - Funcionários

CEP 30130-007 - Belo Horizonte/MG - Brasil

Tel.: 08007043737

Internet: www.editoraforum.com.br

e-mail: editoraforum@editoraforum.com.br
Editor responsável: Luís Cláudio Rodrigues Ferreira Projeto gráfico e diagramação: Luis Alberto Pimenta Revisora: Olga M. A. Sousa

Pesquisa jurídica: Fátima Ribeiro - OAB/MG 74868

Bibliotecária: Nilcéia Lage de Medeiros

CRB 1545/MG 6a região

Os conceitos e opiniões expressas nos trabalhos assinados são de responsabilidade exclusiva de seus autores.

Impressa no Brasil / Printed in Brazil

Distribuída em todo Território Nacional 


\title{
A Lei de Improbidade Administrativa e o Princípio da Proporcionalidade
}

\author{
Anderson Sant'Ana Pedra* \\ Mestre em Direito pela FDC/RJ. Especialista em Direito Público pela Consultime/Cândido Mendes/ES. \\ Chefe da Consultoria Jurídica do TCEES. Advogado da ASSESP - Assessoria Jurídica Especializada. \\ Consultor do DPCC - Direito Público Capacitação e Consultoria. Professor da UVV na graduação \\ e na pós-graduação.
}

Sumário: 1 Introdução - 2 Considerações iniciais - 3 Natureza constitucional da improbidade administrativa $\mathbf{- 4}$ Os sujeitos passivo e ativo na LIA - $\mathbf{5}$ Dos atos de improbidade administrativa - 6 Dos atos de improbidade administrativa que atentam contra os princípios da administração pública - 6.1 Princípio da proporcionalidade - 7 Da utilização sensata da LIA - 8 Considerações finais

\section{Introdução}

A improbidade administrativa é um fenômeno que pode ser estudado por diversas áreas do conhecimento humano, vez que sua prática evidencia desvios éticos, psicológicos, jurídicos, etc. Contudo, a análise aqui efetuada restringir-se-á somente ao aspecto da ciência jurídica, e de forma mais puntual visualizará o princípio da proporcionalidade conjuntamente com a improbidade administrativa.

A matéria tem berço constitucional - improbidade administrativa: (art. 37, $\S 4^{\circ}$ ), sendo que sua eficácia foi integralizada com o advento da Lei $\mathrm{n}^{\circ} 8.429$ de 02 de junho de 1992, apelidada de Lei de Improbidade Administrativa - LIA; e princípio da proporcionalidade (art. $5^{\circ}$, LIV). ${ }^{1}$

A LIA já completou mais de dez anos de existência e é digna de reconhecimento, tendo representado certo avanço no tocante a reparação judicial dos danos causados pelos maus administradores, porém, ainda está

\footnotetext{
*<andersonpedra@dpcc.com.br>.

1 Nesse sentido: MENDES, Gilmar Ferreira. Direitos Fundamentais e Controle de Constitucionalidade: Estudos de Direito Constitucional. 2. ed. rev. ampl. São Paulo: Celso Bastos, 1999, p. 87, apontando que o princípio da proporcionalidade é plenamente compatível com a ordem constitucional brasileira, destacando, inclusive, que a jurisprudência do SUPREMO TRIBUNAL FEDERAL evoluiu para reconhecer que esse princípio tem hoje sua sedes materiae no art. 5, inciso LIV da Constituição brasileira de 1988; BUECHELE, Paulo Armínio Tavares. O Princípio da Proporcionalidade e a Interpretação da Constituição. Rio de Janeiro: Renovar, 1999, p. 148; OLIVEIRA, Fábio Corrêa Souza de. Por uma Teoria dos Princípios: o Princípio Constitucional da Razoabilidade. Rio de Janeiro: Lumen Juris, 2003, p. 109. Em sentido contrário: BONAVIDES, Paulo. Curso de Direito Constitucional. 11. ed. rev. atual. e ampl. São Paulo: Malheiros, 2001, p. 395: "No Brasil a proporcionalidade pode não existir enquanto norma geral de direito escrito, mas existe como norma esparsa no texto constitucional. A noção mesma se infere de outros princípios que Ihe são afins, entre os quais avulta, em primeiro lugar, o princípio da igualdade, [...].".
} 
longe de resolver o problema a contento. Ao passo que avançou em alguns pontos do combate a corrupção - e sem esquecer que tem de avançar ainda mais -, em outro enfrentou verdadeiro revés, como se deu com a criação do foro por prerrogativa de função, que somente há pouco tempo recebeu tinta forte por parte do Supremo Tribunal Federal que considerou tal prerrogativa (de índole legal) como inconstitucional. ${ }^{2}$

O enfoque aqui dado ao tema ainda tem sido tímido pela doutrina nacional, razão pela qual o enfrentamos com o intuito de trazer à baila discussão que se mostra importantíssima para a prática administrativa, sabendo desde já que este estudo é tão somente um ponto de partida, deixando um porto seguro para singrar num oceano desconhecido, correndo o risco, inclusive, de ver essa tese ir a pique, mas escoro-me em Fernando Pessoa, afinal: "navegar é preciso, viver não é preciso".

\section{Considerações iniciais}

Historicamente, pode-se afirmar que o tema improbidade administrativa foi concebido juridicamente desde a Constituição Republicana de 1891, quando estabeleceu como crime de responsabilidade os atos do Presidente atentatórios à probidade da administração (art. 54, §6 $6^{\circ}$ ).

Com o passar dos tempos a matéria foi cuidada tanto em nível constitucional como em nível infra-constitucional, sendo que a partir do Texto Magno de 1988 adquiriu novas formas de interpretação e regulação, haja vista que a nova ordem constitucional reformulou vários princípios e garantias constitucionais, sem olvidar também da valorização do papel do cidadão perante o Estado, restando instrumentalizados controles efetivos ao poder do Estado, ou melhor, dos agentes que agem em nome do Estado.

Com a promulgação da LIA o sistema normativo de prevenção e combate a improbidade administrativa restou fortalecido, principalmente porque inovou, para melhor, ao estabelecer que atos de improbidade administrativa não mais se restringem ao enriquecimento ilícito, para comportarem tantos os atos dolosos ou culposos que causam lesam ao erário, como aqueles atentatórios aos princípios que regem a Administração Pública.

\section{Natureza constitucional da improbidade administrativa}

\footnotetext{
2 ADI 2797 proposta pela Associação Nacional dos Membros do Ministério Público (Conamp) julgada em 15 de setembro de 2005 por maioria de votos $(7 \times 5)$
}

A \& C R. de Dir. Administrativo e Constitucional, Belo Horizonte, ano 5, n. 22, p. 167-180, out./dez. 2005 
Para o estudo de qualquer tema da ciência jurídica, inclusive a improbidade administrativa, imperioso é raciocinar a partir do Texto Constitucional.

A Constituição é o diploma fundamental de um País, é o instrumento que traça as diretrizes a serem observadas por toda a comunidade e pelo próprio Estado, assegura ainda direitos e deveres para todos os cidadãos e impõe certos comportamentos à Administração, bem como estrutura o exercício do poder político.

Em matéria de improbidade administrativa dispõe a Constituição brasileira de 1988:

Art. 15. É vedada a cassação de direitos políticos, cuja perda ou suspensão só se dará nos casos de:

$\mathrm{V}$ - improbidade administrativa, nos termos do art. $37, \S 4^{\circ}$.

Art. 37. A Administração pública direta e indireta de qualquer dos Poderes da União, dos Estados, do Distrito Federal e dos Municípios obedecerá aos princípios de legalidade, impessoalidade, moralidade, publicidade e eficiência e, também, ao seguinte:

..

$\S 4^{\circ}$ Os atos de improbidade administrativa importarão a suspensão dos direitos políticos, a perda da função pública, a indisponibilidade dos bens e o ressarcimento ao erário, na forma e gradação previstas em lei, sem prejuízo da ação penal cabível.

Analisando superficialmente os enunciados constitucionais trasladados verifica-se facilmente a intenção do legislador constituinte em separar as tutelas civis e penais (“... sem prejuizo da ação penal”) dos atos de improbidade administrativa, não podendo haver confusão nesse tocante - a natureza jurídica da ação prevista na LIA é cível, consoante sentido da própria Lei Fundamental.

\section{Os sujeitos passivo e ativo na LIA}

A Lei de Improbidade Administrativa delimita em seu artigo vestibular o sujeito passivo dos atos de improbidade administrativa, senão vejamos:

Art. $1^{\circ}$ Os atos de improbidade praticados por qualquer agente público, servidor ou não, contra a administração direta, indireta ou fundacional de qualquer dos Poderes da União, dos Estados, do Distrito Federal, dos Municípios, de

A \& C R. de Dir. Administrativo e Constitucional, Belo Horizonte, ano 5, n. 22, p. 167-180, out./dez. 2005 
Território, de empresa incorporada ao patrimônio público ou de entidade para cuja criação ou custeio o erário haja concorrido ou concorra com mais de cinqüenta por cento do patrimônio ou da receita anual, serão punidos na forma desta Lei.

Veja que o legislador considerou como sujeito passível de ser atingido por um ato de improbidade administrativa tanto a administração direta, como a indireta de qualquer dos Poderes da União, dos Estados, do Distrito Federal, dos Municípios, de Território; bem como as empresas incorporadas ao patrimônio público ou as entidades cuja criação ou custeio o erário tenha concorrido ou concorra com mais de cinqüenta por cento do patrimônio ou da receita anual.

Já no tocante ao sujeito ativo a Lei de Improbidade Administrativa delimita do seguinte modo:

Art. $2^{\circ}$ Reputa-se agente público, para os efeitos desta Lei, todo aquele que exerce, ainda que transitoriamente ou sem remuneração, por eleição, nomeação, designação, contratação ou qualquer outra forma de investidura ou vínculo, mandato, cargo, emprego ou função nas entidades mencionadas no artigo anterior.

Art. $3^{\circ}$ As disposições desta Lei são aplicáveis, no que couber, àquele que, mesmo não sendo agente público, induza ou concorra para a prática do ato de improbidade ou dele se beneficie sob qualquer forma direta ou indireta.

Tem-se que o conceito de agente público, para os efeitos da LIA, é mais abrangente do que o comumente adotado em outros ramos do Direito Público. ${ }^{3}$

À mingua de uma maior uniformidade terminológica, tanto da doutrina quanto da jurisprudência, a expressão agentes públicos utilizada pela LIA deve ser considerada o gênero do qual emanam as diversas espécies.

Para o que se pretende nesse trabalho poder-se-ia, até mesmo, adotar o conceito clássico de agente público utilizado no direito administrativo na pena de Meirelles:

São todas as pessoas físicas incumbidas, definitiva ou transitoriamente, do exercício de alguma função estatal.

Os agentes públicos, gênero que acima conceituamos, repartem-se inicialmente em cinco espécies ou categorias bem diferençadas, a saber: agentes políticos,

${ }^{3}$ Cf. PAZZAGLINI FILHO, Marino. Lei de Improbidade Administrativa Comentada. São Paulo: Atlas, 2002, p. 
agentes administrativos, agentes honoríficos, agentes delegados e agente credenciados, que, por sua vez, se subdividem em subespécies ou subcategorias, como veremos a seu tempo. ${ }^{4}$

Não destoando desse clássico entendimento, tem-se Bandeira de Mello lecionando no sentido de que a expressão agentes públicos é a mais ampla possível que se pode conceber para designar genérica e indistintamente os sujeitos que servem ao Poder Público. ${ }^{5}$

De forma mais específica observa-se a seguinte lição de Emerson Garcia:

Como se constata pela análise do artigo acima transcrito [art. $2^{\circ}$ ], a concepção de agente público não foi construída sob uma perspectiva meramente funcional, sendo definido o sujeito ativo a partir da identificação do sujeito passivo dos atos de improbidade, havendo um nítido entrelaçamento entre as duas noções.

Trata-se de conceito amplo que abrange os membros de todos os Poderes, qualquer que seja a atividade desempenhada,...

Em suma, a LIA pode (deve) ser aplicada tanto aos agentes públicos quanto ao particular que "induza ou concorra para a prática do ato de improbidade ou dele se beneficie sob qualquer forma direta ou indireta”.

\section{Dos atos de improbidade administrativa}

Em sentido material a LIA sanciona atos que importam enriquecimento ilícito (art. $9^{\circ}$ ), que causam prejuizo ao erário (art. 10) e que atentam contra os princípios da administração pública (art. 11).

Vejamos o que prescrevem esses dispositivos:

Art. $9^{\circ}$ Constitui ato de improbidade administrativa importando enriquecimento ilícito auferir qualquer tipo de vantagem patrimonial indevida em razão do exercício de cargo, mandato, função, emprego ou atividade nas entidades mencionadas no Art. $1^{\circ}$ desta Lei, e notadamente:

Art. 10. Constitui ato de improbidade administrativa que causa lesão ao erário, qualquer ação ou omissão, dolosa ou culposa, que enseje perda patrimonial, desvio, apropriação, mal baratamento ou dilapidação dos bens ou haveres das

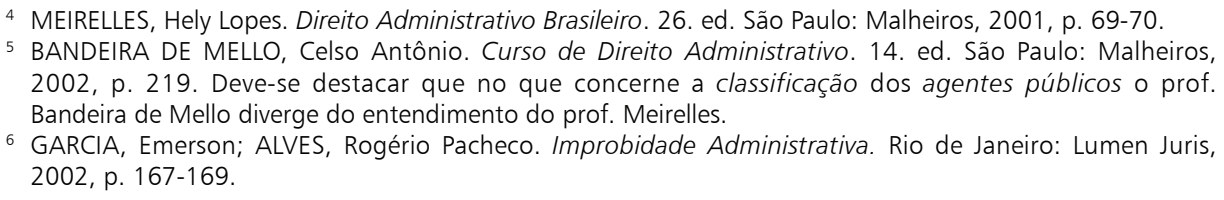

A \& C R. de Dir. Administrativo e Constitucional, Belo Horizonte, ano 5, n. 22, p. 167-180, out./dez. 2005 
entidades referidas no Art. $1^{\circ}$ desta Lei, e notadamente:

Art. 11. Constitui ato de improbidade administrativa que atenta contra os princípios da administração pública qualquer ação ou omissão que viole os deveres de honestidade, imparcialidade, legalidade, e lealdade às instituições, e notadamente:

Já o art. 12 da LIA traz as sanções passíveis de aplicação ao agente público, podendo ser de maior ou de menor intensidade, de acordo com a natureza do ato praticado pelo agente público, estabelecendo:

Art. 12. Independentemente das sanções penais, civis e administrativas, previstas na legislação específica, está o responsável pelo ato de improbidade sujeito às seguintes cominações:

I - na hipótese do art. $9^{\circ}$, perda dos bens ou valores acrescidos ilicitamente ao patrimônio, ressarcimento integral do dano, quando houver, perda da função pública, suspensão dos direitos políticos de oito a dez anos, pagamento de multa civil de até três vezes o valor do acréscimo patrimonial e proibição de contratar com o Poder Público ou receber benefícios ou incentivos fiscais ou creditícios, direta ou indiretamente, ainda que por intermédio de pessoa jurídica da qual seja sócio majoritário, pelo prazo de dez anos;

II - na hipótese do art. 10, ressarcimento integral do dano, perda dos bens ou valores acrescidos ilicitamente ao patrimônio, se concorrer esta circunstância, perda da função pública, suspensão dos direitos políticos de cinco a oito anos, pagamento de multa civil de até duas vezes o valor do dano e proibição de contratar com o Poder Público ou receber benefícios ou incentivos fiscais ou creditícios, direta ou indiretamente, ainda que por intermédio de pessoa jurídica da qual seja sócio majoritário, pelo prazo de cinco anos;

III - na hipótese do art. 11, ressarcimento integral do dano, se houver, perda da função pública, suspensão dos direitos políticos de três a cinco anos, pagamento de multa civil de até cem vezes o valor da remuneração percebida pelo agente e proibição de contratar com o Poder Público ou receber benefícios ou incentivos fiscais ou creditícios, direta ou indiretamente, ainda que por intermédio de pessoa jurídica da qual seja sócio majoritário, pelo prazo de três anos.

Parágrafo único. Na fixação das penas previstas nesta Lei o juiz levará em conta a extensão do dano causado, assim como o proveito patrimonial obtido pelo agente.

6 Dos atos de improbidade administrativa que atentam contra os princípios da administração pública

O escopo desse trabalho é analisar a improbidade administrativa frente aos princípios da Administração Pública, mormente o princípio da 


\section{proporcionalidade.}

Da dicção do art. 11 pode-se concluir que se constitui em ato de improbidade administrativa qualquer ato que atente contra quaisquer dos princípios da Administração Pública. Muito embora a redação deste dispositivo (art. 11, caput) não tenha sido de boa qualidade, essa assertiva não resta prejudicada.

Pazzaglini Filho sobre o tema leciona:

Embora a redação do dispositivo não tenha sido a mais apropriada, pois seria de maior rigor ou precisão reiterar os princípios constitucionais basilares que informam a atuação pública elencados no art. 37, caput, da Carta Magna (legalidade, impessoalidade, moralidade, publicidade e eficiência), a circunstância de constar dele a expressão violação da legalidade elucida, sem dúvidas, que o preceito compreende a transgressão dos demais princípios constitucionais que instruem, condicionam, limitam e vinculam a atuação dos agentes públicos $[\ldots]^{7}$

São inúmeros os princípios que direcionam a Administração Pública, inclusive com berço constitucional, podendo-se destacar: legalidade, impessoalidade, moralidade, impessoalidade, publicidade, eficiência, motivação, interesse público, autotutela, proporcionalidade e etc.

O art. 11 da LIA que cuida dos atos que atentam contra os princípios a Administração Pública, para alguns autores, trata-se de uma norma residual em relação às que tratam das duas outras modalidades de atos de improbidade, pois a afronta a legalidade faz parte de sua contextura. ${ }^{8}$

A importância dos princípios, em qualquer Ciência, evidencia-se no fato de ser irrealizável fazer ciência desconsiderando os princípios, afinal, nenhum conhecimento é possível sem sustentáculo em princípios, sem pressupostos que se admitem como verdades, independente da experiência.

O direito, como sabido, se constitui num organismo, num sistema, e todo sistema é instrumento de uma finalidade, é encarnação de um valor; a sua unidade espiritual, a sua harmonia interior se assenta nas idéias que lhe são imanentes e nenhum sistema adquire significação, ou pode ser entendido e explicado sem referência aos seus princípios. ${ }^{9}$

Miguel Reale com propriedade leciona:

A nosso ver, princípios gerais de direito são enunciações normativas de valor genérico, que condicionam e orientam a compreensão do ordenamento jurídico, quer para a sua aplicação e integração, quer para a elaboração de novas normas.

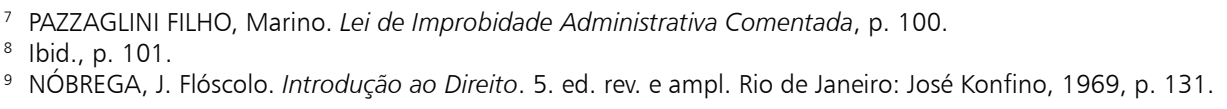


Cobrem, desse modo, tanto o campo da pesquisa pura do Direito quanto o de sua atualização prática. ${ }^{10}$

Esses princípios, por vezes, não vêm declarados explicitamente nos enunciados normativos, mas estão implícitos neles e podem ser descobertos, como foram os princípios científicos.

No dizer de Reale os princípios são eficazes independentemente do texto legal. Este, quando os consagra, dá-lhes força cogente, mas não lhes altera a substância, constituindo um jus prévio e exterior à lex. ${ }^{11}$

Por princípio deve-se entender uma espécie de norma jurídica diversa das meras regras, e que estabelece o ponto de partida e os caminhos possíveis a serem seguidos pelo aplicador do direito.

De acordo com os ensinamentos de Geraldo Ataliba, tem-se que:

Os princípios são as linhas mestras, os grandes nortes, as diretrizes magnas do sistema jurídico. Apontam os rumos a serem seguidos por toda a sociedade e obrigatoriamente perseguidos pelos órgãos do governo (poderes constituídos).

Eles expressam a substância última do querer popular, seus objetivos e desígnios, as linhas mestras da legislação, da administração e da jurisdição. Por estas não podem ser contrariados; têm que ser prestigiados até as últimas conseqüências. ${ }^{12}$

Ao invocar os princípios do direito, o aplicador investiga o pensamento mais alto da cultura jurídica, perquirindo o pensamento filosófico sobranceiro ao sistema, ou as idéias estruturais do regime, impondo, por consectário lógico, a regra em que dada espécie se contém implícita no organismo jurídico nacional, permitindo ao aplicador do direito suprir a deficiência legislativa com a adoção de um cânon que o legislador não chegou a ditar sob a forma de preceito, mas que se contém imanente no espírito do sistema jurídico. ${ }^{13}$

Inquestionável que os princípios do direito são fonte de máxima importância, contudo da mais difícil utilização, pois exigem do aplicador do direito um manuseio com instrumentos mais abstratos, complexos e de idéias de maior teor cultural do que os preceitos singelos de aplicação quotidiana.

Hart, em seu pós-escrito dirigido às críticas que seu pensamento recebeu, ensina que os princípios jurídicos diferem das demais regras de "tudo

\footnotetext{
${ }^{10}$ REALE, Miguel. Lições Preliminares de Direito. 25. ed. São Paulo: Saraiva, 2001, p. 306-307.

11 Ibid., p. 307.

${ }^{12}$ ATALIBA, Geraldo. República e Constituição. 2. ed. atual. São Paulo: Malheiros, 1998, p. 34

13 PEREIRA, Caio Mário da Silva. Instituições de Direito Civil. 6. ed. Rio de Janeiro: Forense, 1995, v. I, p. 49.
}

A \& C R. de Dir. Administrativo e Constitucional, Belo Horizonte, ano 5, n. 22, p. 167-180, out./dez. 2005 
ou nada" porque, quando são aplicáveis, não "obrigam" a uma decisão, mas apontam para uma decisão, ou afirmam uma razão que pode ser afastada. E comenta, ainda, o entendimento de Dworkin, para quem os princípios jurídicos diferem das regras porque têm uma dimensão de peso, mas não de validade, e, por isso, sucede que, em conflito com outro princípio de maior peso, um princípio pode ser afastado, não logrando determinar a decisão, mas, não obstante, sobreviverá intato para ser utilizado noutros casos em que possa prevalecer em concorrência com qualquer outro princípio de menor peso. Por outro lado, as regras ou são válidas ou inválidas, mas não tem essa dimensão de peso, por isso quando entrarem em conflito, apenas uma delas pode ser válida e a outra reformulada, de forma a tornar a norma coerente com a sua concorrente e, conseqüentemente, inaplicável ao caso dado. ${ }^{14}$

Compulsando as lições de Dworkin observa-se que para ele os princípios estão acima da prática, e é a eles que os aplicadores do direito e os cidadãos estão adstritos, ${ }^{15}$ afinal os princípios são as idéias centrais de um sistema, ao qual dão sentido lógico, harmonioso e racional, permitindo a compreensão de seu modo de se organizar, sendo imprescindível sua identificação pelo cientista jurídico, sob pena deste não poder jamais trabalhar com o direito. ${ }^{16}$

Longe vai a época em que os princípios eram considerados como elementos secundários no Direito, aos quais se recorria apenas na hipótese de lacuna legal. A doutrina e a jurisprudência contemporâneas reforçam ao extremo o papel normativo dos princípios, acentuando a sua multifuncionalidade no ordenamento constitucional. ${ }^{17}$

A lesão a um princípio é indubitavelmente a mais grave das lesões ao ordenamento jurídico, porque sem princípio não há ordenamento jurídico, e sem ordenamento jurídico não há garantia para as liberdades cujo exercício somente se faz possível fora do reino do arbítrio e dos poderes absolutos.

Bandeira de Melo afirma quanto à violação de um princípio:

\footnotetext{
14 HART, Herbert L. A. O Conceito de Direito. 2. ed. Trad. A. Ribeiro Mendes. Lisboa: Calouste Gulbenkian, 1986, p. 323.

15 DWORKIN, Ronald. O Império do Direito. Trad. Jefferson Luiz Camargo. São Paulo: Martins Fontes, 1999, p. 492.

${ }^{16}$ SUNDFELD, Carlos Ari. Fundamentos de Direito Público. 4. ed. rev. aum. e atual. São Paulo: Malheiros, 2000, p. 143.

17 PEDRA, Anderson Sant'Ana. Interpretação e Aplicabilidade da Constituição: em busca de um Direito Civil Constitucional. Revista de Direito Administrativo, Rio de Janeiro, v. 232, abr./jun. 2003, p. 183.
} 
É a mais grave forma de ilegalidade ou inconstitucionalidade, conforme o escalão do princípio atingido, porque representa insurgência contra todo o sistema, subversão de seus valores fundamentais, contumélia irremissível a seu arcabouço lógico e corrosão de sua estrutura mestra. ${ }^{18}$

Os princípios de Direito põem-se, destarte, como as bases teóricas ou as razões lógicas do ordenamento jurídico, que deles recebe o seu sentido ético, a sua medida racional e a sua força vital, ${ }^{19}$ por isso ferir um princípio é muito mais grave do que ferir uma regra, e é nesse jaez que o princípio da proporcionalidade será abordado.

\subsection{Princípio da proporcionalidade ${ }^{20}$}

O princípio da proporcionalidade surgiu ligado à idéia de limitação do Poder no séc. XVIII. O cânone da proporcionalidade compreende, nessa época, a área administrativa e a área penal. Nesse sentido, é detentor de raízes iluministas, sendo mencionado por Montesquieu e por Beccaria ambos tratavam sobre a proporcionalidade das penas em relação aos delitos. ${ }^{21}$

O princípio da proporcionalidade sempre teve seu campo de incidência mais tradicional no âmbito da atuação do Poder Executivo. Estudado precipuamente na área do Direito Administrativo, funcionava ele como medida de legitimidade do exercício do poder de polícia e da interferência dos entes públicos na vida privada.

Vale assinalar que o princípio da proporcionalidade foi teorizado no bojo da transformação do Estado de polícia para o Estado de direito, com a finalidade de controlar o poder coativo dos governantes, denominado poder de polícia, a fim de que o seu exercício ficasse limitado pela justa proporção entre os fins objetivados pela atuação do poder público e os meios utilizáveis para o seu atingimento. ${ }^{22}$

\footnotetext{
18 BANDEIRA DE MELLO, Celso Antônio. Elementos de Direito Administrativo. 3. ed. São Paulo: Malheiros, 1992, p. 300

${ }^{19}$ REALE, Miguel. Lições preliminares de Direito, p. 319.

${ }^{20} \mathrm{Em}$ virtude da indefinição terminológica tanto pela doutrina quanto pela jurisprudência, preferimos ficar ombreado com aqueles que consideram a razoabilidade e proporcionalidade como sinônimos. Cf. nesse sentido: BASTOS, Celso Ribeiro. Hermenêutica e Interpretação Constitucional. São Paulo: Celso Bastos, 1997, p. 175; MENDES, Gilmar Ferreira. Direitos Fundamentais e Controle de Constitucionalidade, p. 87; BARROSO, Luís Roberto. Interpretação e Aplicação da Constituição. 3. ed. rev. e atual. São Paulo: Saraiva, 1999, p. 215; BUECHELE, Paulo Armínio Tavares. O Princípio da Proporcionalidade e a Interpretação da Constituição, p. 175; TÁCITO, Caio. O Princípio da Razoabilidade das Leis. In: . Temas de Direito Público: Estudos e Pareceres. Rio de Janeiro: Renovar, 1997, v. 1, p. 487-495. Frise-se que o SUPREMO TRIBUNAL FEDERAL utiliza ambos os termos sem distinção.

21 PENALVA, Ernesto Pedraz, apud, STUMM, Raquel Denize. Princípio da Proporcionalidade no Direito Constitucional Brasileiro. Porto Alegre: Liv. do Advogado, 1995, p. 78.
} 
Pode-se afirmar então que tal princípio foi cunhado no Direito Administrativo, ao tempo do florescimento do jusnaturalismo, como idéia de limitação do poder de polícia, exatamente para coibir medidas excessivamente gravosas aos direitos do cidadão. ${ }^{23}$

Nessa vertente Augustín Gordillo assinalou:

A decisão "discricionária" do funcionário será ilegítima, apesar de não transgredir nenhuma norma concreta e expressa, se é "irrazoável”, o que pode ocorrer, principalmente, quando: a) não dê os fundamentos de fato ou de direito que a sustentam ou; b) não leve em conta os fatos constantes do expediente ou públicos e notórios; ou se funde em fatos ou provas inexistentes; ou c) não guarde uma proporção adequada entre os meios que emprega e o fim que a lei deseja alcançar, ou seja, que se trate de uma medida desproporcionada, excessiva em relação ao que se quer alcançar. ${ }^{24}$

O princípio da proporcionalidade dizia primitivamente respeito ao problema da limitação do poder executivo, sendo considerado como medida para as restrições administrativas da liberdade individual. É com esse sentido que a teoria do Estado o considera, já no séc. XVIII, como máxima suprapositiva, e é com esse sentido que ele foi introduzido, no séc. XIX, no Direito Administrativo como princípio geral do direito de polícia, sendo posteriormente erigido à dignidade de princípio constitucional. ${ }^{25}$

A fórmula utilizada aqui no Brasil para a aplicação do princípio da proporcionalidade foi importada da França na figura tradicional originária do Direito Administrativo identificada como détournement de pouvoir, isto é, o desvio ou excesso de poder. ${ }^{26}$

O princípio da proporcionalidade se caracteriza pelo fato de presumir a existência de relação adequada entre um ou vários fins determinados e os meios com que são levados a cabo, diluindo-se em um conjunto de proposições (subprincípios) que não o libertam de uma dimensão excessivamente subjetiva. É proporcional (razoável) o que seja conforme a razão, supondo equilíbrio, adequação, moderação e harmonia; o que não seja

22 SIQUEIRA CASTRO, Carlos Roberto de. A Constituição Aberta e os Direitos Fundamentais: Ensaios sobre o constitucionalismo pós-moderno e Comunitário. Rio de Janeiro: Forense, 2003, p. 78.

${ }_{23}$ TOLEDO, Suzana de Barros. O Princípio da Proporcionalidade e o Controle da Constitucionalidade das Leis Restritivas de Direitos Fundamentais. Brasília: Brasília Jurídica, 1996, p. 211-212.

${ }^{24}$ GORDILLO, Augustín. Princípios Gerais de Direito Público. Trad. Marco Aurélio Greco. São Paulo: Revista dos Tribunais, 1977, p. 183-184.

${ }^{25}$ CANOTILHO, José Joaquim Gomes. Direito Constitucional e Teoria da Constituição. 4. ed. Coimbra: Almedina, 1998, p. 265-266.

${ }^{26}$ BARROSO, Luís Roberto. Interpretação e Aplicação da Constituição, p. 225. 
arbitrário ou caprichoso; o que corresponda ao senso comum, aos valores vigentes em dado momento ou lugar.

O princípio da proporcionalidade, tal como desenhado no direito alemão de onde se irradiou para os demais ordenamentos jurídicos, desdobra-se em três aspectos: a) adequação (Geeinigkeit); b) exigibilidade (Erförderlichkeit); e, c) proporcionalidade em sentido estrito (Verhältnismässigkeit), os quais, em conjunto, dão-lhe a densidade indispensável para alcançar a funcionalidade pretendida pelos operadores do direito. No seu emprego, sempre se tem em vista o fim colimado nas disposições constitucionais a serem interpretadas, fim esse que pode ser atingido por diversos meios, entre os quais se haverá de optar de forma a não ferir o ordenamento jurídico.

Nesses termos haverá violação do princípio da proporcionalidade, com ocorrência de arbítrio, sempre que os meios destinados a realizar um fim não sejam por si mesmos apropriados e ou quando a desproporção entre meios e fim seja particularmente evidente (manifesta).

Paulo Bonavides, citando Braibant, afirma que se deve acrescer às bases do princípio da proporcionalidade (junção fim e meio) um terceiro elemento, a saber, a situação de fato; estabelecendo então a relação triangular fim, meio e situação, para corrigir insuficiências da dualidade antecedente. ${ }^{27}$

Desse modo, pode-se afirmar que deve o Ministério Público, os Tribunais de Contas, e porque não dizer também a sociedade, ficar atenta aos atos administrativos praticados com objetivos outros que não atender o interesse público (fim), e, principalmente àqueles atos travestidos de uma legalidade formal, mas que por de trás são excessivos por percorrerem caminhos (meios) inadequados, ferindo assim o princípio da proporcionalidade.

Não se pode permitir que, por exemplo, agentes em final de mandato adquiram uma quantidade abusiva de determinado material, incontestavelmente fora da média de consumo, mas dentro de um "perfeito" processo licitatório, pelo menos do ponto de vista formal, tendo por objetivo, talvez, "zerar o caixa” para o próximo administrador.

Outra conduta digna de receber o adjetivo de "ímproba" é aquela em que um agente público adquire uma camionete bem equipada, luxuosa e com o prévio certame licitatório, mas que terá por único fim o combate ao mosquito transmissor da dengue.

Comportamento como estes acontecem em todos brasis, e é inaceitável que o Administrador utilize o ordenamento jurídico como um pálio, alegando que cumpriu o procedimento para que ocorresse uma

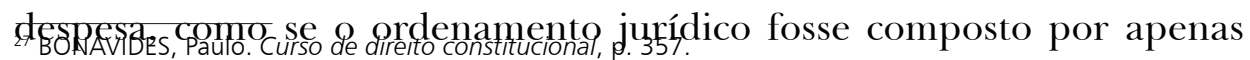

A \& C R. de Dir. Administrativo e Constitucional, Belo Horizonte, ano 5, n. 22, p. 167-180, out./dez. 2005 
normas regras.

\section{Da utilização sensata da LIA}

Não se pode deixar de ressaltar que a LIA, como visto, é de fato um diploma legal de sanção constitucional extrema e que ao ser aplicada deve ser "cercada das devidas cautelas para não transpor os limites finalísticos traçados pelo ordenamento". ${ }^{28}$

Tem-se que a matriz política e jurídica das sanções é punir atos efetivamente desonestos que causam enriquecimento ilícito, prejuízo mensurável ao erário e resultados fortemente contrários a moralidade administrativa, ou seja, condutas com resultados moralmente reprováveis face à disciplina interior da Administração. ${ }^{29}$

Juarez Freitas com sua tinta forte diz que: "imprescindível para a aplicação das penalidades e para que a ação catalogável como a de um ímprobo, que se caracterize o destoamento nítido e manifesto da moralidade e não mera ameaça." ${ }^{30}$ Assim, há que se ter bom senso no sentido de não se aplicar as sanções cominadas na LIA às condutas culposas leves ou levíssimas, ainda mais se desacompanhadas de prejuízo ao erário. ${ }^{31}$

A conduta ilícita do agente público para tipificar ato de improbidade administrativa deve ter os seguintes traços comuns ou característicos de todas as modalidades de improbidade administrativa: desonestidade, má-fé e falta de probidade no trato da coisa pública. ${ }^{32}$

No que aqui foi explorado, pode-se dizer que existirão casos em que o agente público não observará na plenitude os princípios administrativistas, mas nem por isso merecerá sofrer as sanções trazidas pela LIA.

Não se pode deixar de frisar que ilegitimidade ${ }^{33}$ não é sinônimo de improbidade e a ocorrência daquela, por si só, não configura ato de improbidade administrativa, até porque o vocábulo latino improbitate tem o significado de "desonestidade" e a expressão improbus administrator quer dizer "administrador desonesto ou de má-fé". ${ }^{34}$

\footnotetext{
${ }^{28}$ FREITAS, Juarez. Do Princípio da Probidade Administrativa e de sua Máxima Efetivação. Revista de Direito Administrativo, Rio de Janeiro, 1996, n. 204, p. 71.

${ }^{29}$ ZAMBROTA, Luciano. Da Lei de Improbidade Administrativa: Observações e Conjecturas Sistemáticas após Dez Anos de Vigência. Revista Brasileira de Direito Público, Belo Horizonte, 2005, n. 9, p. 156.

${ }^{30}$ FREITAS, Juarez. Do Princípio da Probidade Administrativa e de sua Máxima Efetivação, p. 71.

${ }^{31} \mathrm{Cf}$. a LIA: "Art. 12... Parágrafo único. Na fixação das penas previstas nesta Lei o juiz levará em conta a extensão do dano causado, assim como o proveito patrimonial obtido pelo agente."

32 PAZZAGLINI FILHO, Marino. Lei de Improbidade Administrativa Comentada, p. 102

33 Tomamos aqui o instituto da ilegitimidade como ofensa a qualquer norma-princípio, conceito este mais amplo do que a ilegalidade (confronto com uma norma-regra). Cf. nesse sentido: MEIRELLES, Hely Lopes. Direito Administrativo Brasileiro, p. 194.
} 


\section{Considerações finais}

É hora de fazer brilhar o princípio da proporcionalidade no nosso ordenamento constitucional; de retirar o pó do antigo Estado de Direito (o da legalidade) que ofusca o contemporâneo Estado de democrático de direito (o da constitucionalidade), pois se trata de princípio vivo, elástico, e que merece uso jurisprudencial com vigor.

Assim, resta indubitável que o princípio da proporcionalidade é um dos princípios constitucionais-administrativos, logo, merecedor de homenagem cotidiana pelo agente público $\left(\right.$ art. $2^{\circ}$ ), sob pena de praticar ato de improbidade administrativa (art. 11).

Pode-se então asseverar que tendo sido praticado um ato contra a Administração Pública (art. $1^{\circ}$ ) que se mostre: inadequado, desarrazoável, excessivo, abusivo ou arbitrário para o fim pretendido, e também de máfé, deve-se colocar em exercício o soldado de reserva $a^{35}$ talhado no art. 11 da LIA, vez que tal comportamento subsome-se perfeitamente a este enunciado, mesmo que tal ato venha revestido de uma pseudo-legalidade.

Informação bibliográfica deste texto, conforme a NBR 6023:2002 da Associação Brasileira de Normas Técnicas (ABNT):

PEDRA, Anderson Sant'Ana. A Lei de Improbidade Administrativa e o princípio da proporcionalidade. A $\mathcal{E}^{2} C$ Revista de Direito Administrativo e Constitucional, Belo Horizonte, ano 5, n. 22, p. 167-180, out./dez. 2005.

${ }^{44}$ PAZZAGLINI FILHO, Marino. Lei de Improbidade Administrativa Comentada, p. 102. Cf. ainda: FIGUEIREDO, Marcelo. Probidade Administrativa. 2. ed. São Paulo: Malheiros, 1997, p. 21.

${ }^{35}$ Expressão do saudoso Nelson Hungria utilizada para caracterizar as normas residuais. 